\title{
Single-walled and multi-walled carbon nanotubes induce sequence-specific epigenetic alterations in 16 HBE cells
}

\author{
Manosij Ghosh ${ }^{1, *}$, Deniz Öner ${ }^{1, *}$, Radu C. Duca ${ }^{1}$, Bram Bekaert ${ }^{3,4}$, Jeroen A.J. \\ Vanoirbeek $^{1}$, Lode Godderis ${ }^{1,2, \#}$ and Peter H.M. Hoet ${ }^{1, \#}$ \\ ${ }^{1}$ KU Leuven, Department of Public Health and Primary Care, Centre Environment and Health, B-3000 Leuven, Belgium \\ ${ }^{2}$ Idewe, External Service for Prevention and Protection at Work, B-3001 Heverlee, Belgium \\ ${ }^{3}$ Forensic Biomedical Sciences, Department of Imaging and Pathology, KU Leuven, University of Leuven, Leuven, Belgium \\ ${ }^{4}$ Department of Forensic Medicine, Laboratory of Forensic Genetics and Molecular Archaeology, University Hospitals Leuven, \\ Leuven, Belgium \\ *These authors contributed equally to this work and are co-first authors \\ \#Co-last authors \\ Correspondence to: Manosij Ghosh, email: gmanosij@gmail.com, manosij.ghosh@kuleuven.be \\ Peter H.M. Hoet, email: peter.hoet@kuleuven.be \\ Keywords: nanotoxicology; MWCNT; SWCNT; epigenetics; DNA methylation
}

Received: September 19, $2017 \quad$ Accepted: March 15, $2018 \quad$ Published: April 17, 2018

Copyright: Ghosh et al. This is an open-access article distributed under the terms of the Creative Commons Attribution License 3.0 (CC BY 3.0), which permits unrestricted use, distribution, and reproduction in any medium, provided the original author and source are credited.

\section{ABSTRACT}

Recent studies have identified carbon nanotube (CNT)-induced epigenetic changes as one of the key players in patho-physiological response. In the present study, we investigated whether CNT exposure is associated with epigenetic changes in human bronchial epithelial cells (16 HBE), in vitro. We focused on global DNA methylation, methylation of LINE-1 elements and promoter sequence of twelve functionally important genes (SKI, DNMT1, HDAC4, NPAT, ATM, BCL2L11, MAP3K10, PIK3R2, MYO1C, TCF3, FGFR 1 and AGRN). Additionally, we studied the influence of CNT exposure on miRNA expression. Using a LC-MS/MS method and pyrosequencing for LINE-1, we observed no significant changes in global DNA methylation (\%) between the concentrations of multi-walled and single-walled CNT (MWCNT and SWCNT, respectively). Significant changes in sequence-specific methylation was observed in at least one CpG site for DNMT1 (SWCNT), HDAC4 (MWCNT), NPAT/ ATM (MWCNT and SWCNT), MAP3K10 (MWCNT), PIK3R2 (MWCNT and SWCNT) and MYO1C (SWCNT). While changes in DNA methylation of the genes were relatively small, these changes were associated with changes in RNA expression, especially for MWCNT. However, the study did not reveal any significant alteration in the miRNA expression, associated with MWCNT and SWCNT exposure. Based on our results, mainly MWCNT influence DNA methylation and expression of the studied genes and could have significant impact on several critical cellular processes.

\section{INTRODUCTION}

Over the past decade, several aspects of carbon nanotube (CNT)-induced toxicity have been described in both in vitro and in vivo studies [1-7]. Many of these studies have provided conclusive evidences on cytotoxicity, inflammatory response, and genotoxicity. Moreover, in some CNTs, molecular signatures, similar to those observed in cancer, have been identified. Both multi-walled carbon nanotubes (MWCNT) and single-walled carbon nanotubes (SWCNT) have been shown to induce cell cycle arrest and activation of NF- $\mathrm{KB}, \mathrm{AP}-1$, AKT and MAPK signalling pathways [8-11]. Polimeni et al. [12]. reported that MWCNT could promote TGF- $\beta$ secretion and AKT activation, along with the incidence of pulmonary fibrosis in C57BL/6 mice. Vietti et al. [13]. elaborately reviewed the data on alterations in key pathways, associated with CNTinduced pro-inflammatory and pro-fibrotic outcomes. 
Additionally, a limited number of studies have reported adverse effects of CNT exposure in human populations. Of these studies, some have reported significant alterations in immunological markers, miRNA, and mRNA expression. Significant changes in non-coding RNA and mRNA, with key roles in cell cycle regulation-progression, apoptosis and cell proliferation have been reported for workers exposed to MWCNT [14]. Increased levels of KL-6/TGF- $\beta$ have been reported in MWCNT-exposed workers [15]. Vlaanderen et al. [16] also reported adverse effect on immunological markers in workers exposed to MWCNT. In the same population, we observed significant changes in DNA methylation in a number of $\mathrm{CpG}$ sites, located in the promoter regions of DNMT1, HDAC4, SKI, ATM/ NPAT genes [17].

Based on some of these data (in vitro, in vivo and in humans), most CNT have been classified as Group 3 ("Not classifiable as to its carcinogenicity to humans"; MWCNT and SWCNT) and MWCNT-7 has been classified as Group 2B ("Possibly carcinogenic to humans") by the IARC (International Agency for Research on Cancer). However, these studies provide only partial mechanistic explanation as to how the CNT could result in possible carcinogenic response. Changes in epigenetic signature and noncoding RNA, in cancer initiation and progression are well established. Of the epigenetic alterations, methylation of DNA is crucial to cellular processes including chromatin folding and gene expression. Aberrant methylation signatures associated with altered gene expression and dysregulation of key pathways have been observed in cancer [18-21]. In this context, some recent studies [22-26] including that by our group [17, 27-29] have identified epigenetic changes as one of the potential players in CNT-induced pathophysiological response. In our previous study in human monocytes (THP-1) [28] and bronchial epithelial cells (16-HBE) [29], we observed differential methylation of genes in PI3K-AKT-mTOR pathway, JAK-STAT pathway, MAPK pathway, cell cycle, VEGF pathways. The epigenetic changes in pathways from our study were in agreement with that reported by other studies using other endpoints $[8,10,11]$.

Since CNTs are likely to deposit on the lung tissue, studying DNA methylation and subsequent gene expression alterations in these cells will elucidate possible forthcoming adverse effects upon exposure.

Hence, in the present study we have directed our efforts to identification of DNA methylation changes, as possible signatures of CNT exposure and response. We have studied changes in global DNA methylation/ demethylation processes (using LC-MS/MS), and methylation of long interspersed nuclear element (LINE-1). Additionally, to identify specific DNA methylation markers, we studied sequence-specific changes in promoter region of key genes (SKI, DNMT1,
HDAC4, NPAT, ATM, BCL2L11, MAP3K10, PIK3R2, $M Y O 1 C, T C F 3, F G F R 1, A G R N)$ associated with DNA damage repair response and apoptosis (ATM, NPAT, BCL2L11, MAP3K10), epigenetic regulation (DNMT1, HDAC4), among others. To use such markers efficiently, we studied expression of these genes. Among the noncoding RNAs, miRNAs have often been associated with gene regulation and disease phenotypes and are often considered optimal markers. Hence, we studied the changes in CNT- induced miRNA expression profile. We believe that the result obtained from the study will potentially improve the understanding of CNT-induced toxic response.

\section{RESULTS}

\section{Characterization of particles}

The CNT used in the present study were wellcharacterized reference materials from Joint Research Centre (JRC, European Commission) and National Institute of Standards and Technology (NIST, USA). Characterizations of the particle have been published elsewhere [28]. For the present study, we characterized the CNTs for primary shape using Transmission electron microscopy (TEM). Dynamic light scattering (DLS) measurements were performed for the exposure concentrations at two different time points, results of which have been represented in Figure 1A, 1B. While DLS is not an ideal method to determine hydrodynamic diameter for fibres such as CNT, this data has only been used as representative of aggregation state over time. The DLS measurements indicated significant increase in agglomeration at $24 \mathrm{~h}$ compared to that at $1 \mathrm{~h}$.

\section{Global DNA methylation}

The results of \% DNA methylation [5-methylcytosine residues $(5-\mathrm{mC})]$ and \% DNA hydroxymethylation [5-hydroxymethylcytosine residues $(5-\mathrm{hmC})]$ are presented in Figure 2. We did not observe any significant changes in mean value of global DNA methylation (\%) and hydroxymethylation (\%) for MWCNT (\% 5-mC- 4.71- 5.433; \% 5-OHmC- 0.0060$0.0064)$ and SWCNT (\% 5-mC- 4.78- 5.03; \% 5-OHmC0.0049-0.009) treatments, compared to control samples (\%5-mC -5.24; \% 5-OHmC- 0.006).

\section{Methylation of repetitive element LINE-1}

We quantified the LINE-1 methylation levels using pyrosequencing. The percentage of LINE-1 methylation remained mostly unaltered (Figure 3) for MWCNT (53.63 $\pm 0.5)$ and SWCNT (53.21 \pm 0.77$)$, compared to control $(53.15 \pm 0.17)$, while significant changes were observed for decitabine (positive control, $40.74 \pm 0.54$ ). 


\section{Sequence specific methylation and changes in RNA expression}

Expression of several genes selected for the study were significantly altered for MWCNT exposure (BCL2L11, MYOIC, AGRN, SKI, ATM, NPAT, PIK3R2, $T C F 3$, and FGFR1) compared to the vehicle control (Table 1).

The results of pyrosequencing analysis have been presented in Supplementary Table 2. Significant changes in methylation were observed (Figure 4) for the genes either for MWCNT exposure (HDAC4, MAP3K10), SWCNT exposure (MYO1C, NPAT/ATM, DNMT1), or average methylation for both (PIK3R2). While some of the $\mathrm{CpG}$ sites were hypomethylated others were hypermethylated, often within the same gene promoter region. For instance, $\mathrm{CpG} 4$ and $\mathrm{CpG} 6$ of $A T M / N P A T$ promoter were hypermethylated. Interestingly, these $\mathrm{CpG}$ sites were also hypermethylated for decitabine (a known hypomethylating agent). No clear dose response pattern could be observed.

\section{Effect on miRNA expression}

Considering a fold change of $>2$, no significant changes (FDR corrected $p$-value $<0.05$ ) in expression of miRNA (Figure 5) were observed in the cells exposed to MWCNT and SWCNT (Supplementary Figure 3; Supplementary Table 3). Unsupervised hierarchical clustering of samples using the expression of the miRNA ( $n$ $=323$ ), indicated one main cluster comprising the control samples as well as cells exposed to SWCNT and MWCNT.

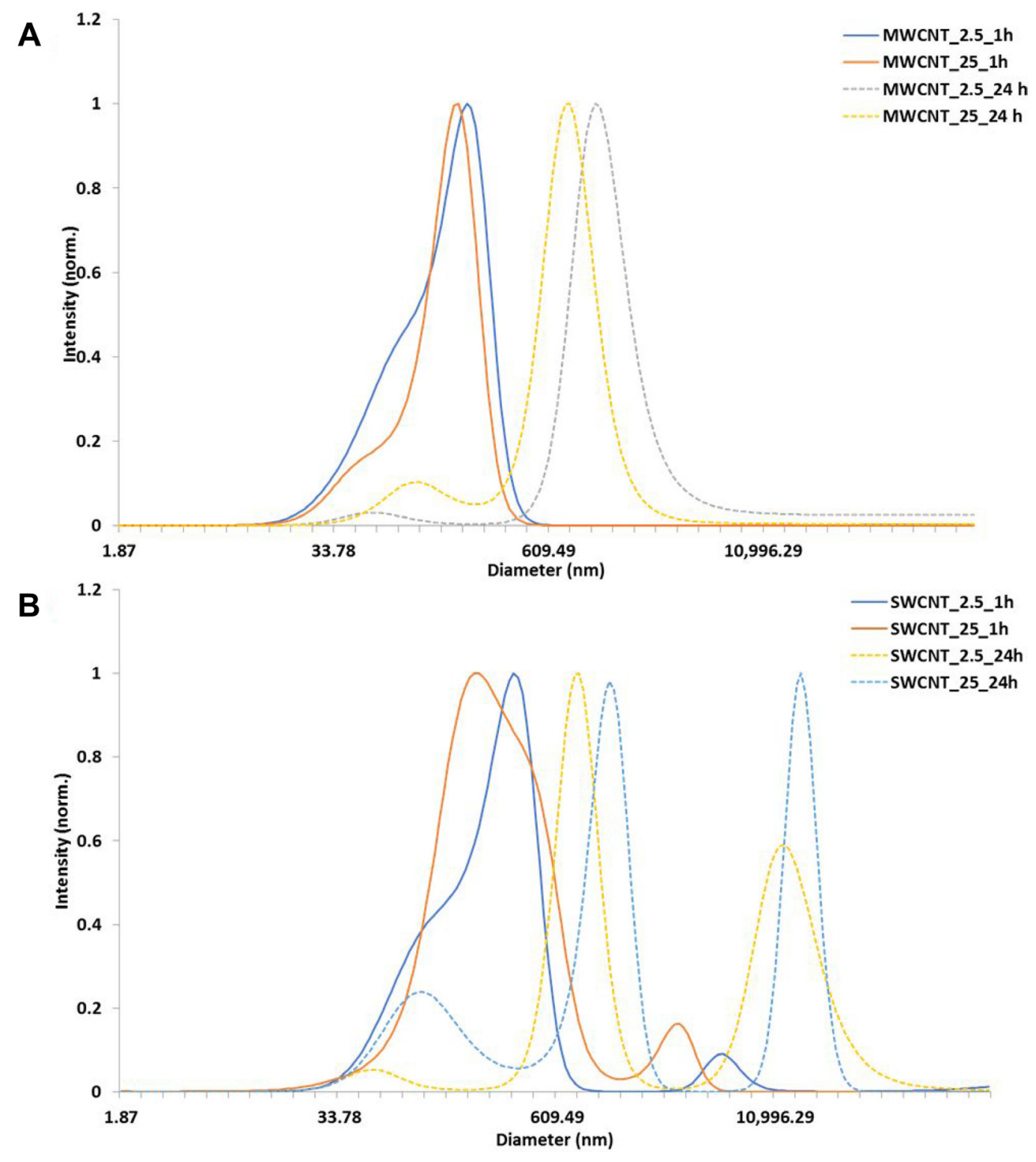

Figure 1: Characterization of carbon nanotubes in exposure medium. (A) DLS measurements of MWCNT (NM 400), (B) DLS of SWCNT in cell culture media at $1 \mathrm{~h}$ and $24 \mathrm{~h}$. 
Table 1: Summary of RNA expression data for the genes studied for pyrosequencing assays

\begin{tabular}{lcccccc}
\hline & \multicolumn{2}{c}{ Control Vs Decitabine } & \multicolumn{2}{c}{ Control Vs MWCNT } & \multicolumn{2}{c}{ Control Vs SWCNT } \\
\hline & $\boldsymbol{l o g} \boldsymbol{F} C$ & $\boldsymbol{F D R}$ & $\boldsymbol{l o g} \boldsymbol{F C}$ & $\boldsymbol{F D R}$ & $\boldsymbol{l o g} \boldsymbol{F C}$ & $\boldsymbol{F D R}$ \\
AGRN & 0.592 & 0.369 & $\mathbf{0 . 5 5 7}$ & $>\mathbf{0 . 0 0 1}$ & 0.057 & 0.821 \\
ATM & 0.068 & 0.906 & $\mathbf{- 0 . 4 3 0}$ & $>\mathbf{0 . 0 0 1}$ & -0.039 & 0.886 \\
BCL2L11 & 0.135 & 0.921 & $-\mathbf{0 . 3 5 7}$ & $>\mathbf{0 . 0 0 1}$ & -0.244 & 0.091 \\
DNMT1 & -0.170 & 0.453 & 0.127 & 0.147 & 0.045 & 0.811 \\
FGFR1 & -0.009 & 0.989 & $\mathbf{0 . 3 1 5}$ & $\mathbf{0 . 0 0 1}$ & 0.103 & 0.615 \\
HDAC4 & -0.469 & 0.509 & 0.026 & 0.871 & 0.006 & 0.986 \\
MAP3K10 & 0.015 & 0.989 & 0.180 & 0.121 & -0.184 & 0.385 \\
MYO1C & 0.367 & 0.781 & $\mathbf{0 . 2 0 6}$ & $\mathbf{0 . 0 1 5}$ & 0.032 & 0.874 \\
NPAT & -0.044 & 0.972 & $-\mathbf{0 . 2 3 1}$ & $\mathbf{0 . 0 0 4}$ & 0.033 & 0.859 \\
PIK3R2 & -0.020 & 0.979 & $\mathbf{0 . 2 7 5}$ & $\mathbf{0 . 0 0 1}$ & -0.038 & 0.843 \\
SKI & 0.806 & 0.126 & $\mathbf{0 . 2 4 3}$ & $\mathbf{0 . 0 0 5}$ & 0.027 & 0.902 \\
TCF3 & 0.062 & 0.942 & $\mathbf{0 . 3 4 6}$ & $\mathbf{> 0 . 0 0 1}$ & 0.054 & 0.777 \\
\hline
\end{tabular}

Values in bold represent statistically significant values, log Fold Change (logFC), false discovery rate (FDR).

\section{DISCUSSION}

Several studies have clearly indicated the ability of CNT to induce DNA damage. Studies that are more recent have reported the effect of CNT on DNA damage repair pathways, post-transcriptional modifications, and dysregulation of genes involved in several critical pathways. Few recent studies have attributed CNT induced epigenetic alterations behind the dysregulation. Most of these signatures bear considerable resemblance to hallmarks of cancer related pathways. Some of the CNTs in use/production have shown evidence of potential carcinogenic response in animal studies. In a published study from our group, we observed, using femtosecond pulsed laser microscopy, localization of SWCNT and MWCNT at nuclear level after $24 \mathrm{~h}$ exposure. Based on the premise of potential carcinogenicity and evidence of nuclear localization, we designed a study to evaluate changes in global DNA methylation/hydroxymethylation levels in $16 \mathrm{HBE}$ cells, in vitro. Additionally, we investigated sequence-specific methylation changes in LINE-1 elements and promoter specific methylation and expression of 12 critical genes involved in DNA damage repair and related pathways.

Altered global DNA methylation has been identified in several diseases [30, 31]. Here, we studied the changes in methylation $(5-\mathrm{mC})$ induced by MWCNT and SWCNT; however, we did not observe significant changes. Additionally, due to the newly identified role of demethylation pathways in cancer [32,33], we studied hydroxymethylation $(5-\mathrm{hmC})$ in the CNT exposed cells. No significant changes in the 5 -mC levels were observed either. We subsequently studied the methylation levels of LINE-1, which is considered a good indicator of global DNA methylation [34]. Sequence specific analysis of
LINE-1 did not reveal significant changes in methylation, except for a single concentration of SWCNT $(25 \mu \mathrm{g} / \mathrm{ml})$ at a $\mathrm{CpG}$ position 3. It must be mentioned that aberrant methylation of LINE-1 has been observed in several diseases [35-37]. From our previous study [28] in monocytic cells and bronchial epithelial cell, despite absence of global methylation changes, we observed methylation changes in gene promoter region of several genes. Hence, in addition to global methylation changes, we wanted to see if certain genes with important role in cellular processes were differentially methylated.

Of the genes selected, we studied the sequencespecific methylation changes in bidirectional promoter for ATM and NPAT genes. ATM is important for an efficient DNA damage response (DDR) mechanism, which involves recruitment of early responders like phosphatidylinositol 3-kinase-related kinases (PIKK) - ataxia-telangiectasia mutated (ATM). ATM codes for serine-threonine kinase which acts by phosphorylating several important genes, ultimately leading to cell cycle arrest, DNA repair, and/ or apoptosis. We observed significant hypermethylation of the region studied, significant for some concentrations of SWCNT. RNA expression was significantly reduced by MWCNT for $\operatorname{ATM}(P<0.001$ FDR corrected) and NPAT $(P<0.001$, FDR corrected $)$ genes. However, the changes in methylation of the sequence in question were not correlated with that of the RNA expression. CpG hypermethylation in ATM gene was of key interest for the present study as it has also been observed for CNT exposure in mice lungs by our group [27]. Interestingly, significant hypermethylation of $\mathrm{CpG}$ position 6, also seen in the present study, was observed for the same sequence region in our study on MWCNT-exposed workers [17]. Additionally, literature clearly reveals that ATM expression is downregulated in several forms of 
cancer including that of breast and lung [38-40]. In the context of epigenetic regulation however, some studies have shown promoter hypermethylation to be associated with reduced ATM expression [41, 42], while other studies have shown no evidence of epigenetic silencing of ATM gene $[43,44]$. Based on the results we propose that CNTinduced downregulation of ATM expression and aberrant promoter methylation might be responsible for reduced DDR efficiency.

With significant functional and sequence similarities to the PIKKs, phosphatidylinositol - 3 kinases (PI3Ks) play key role in signal transduction, essential for cellular functions including cell growth, survival and apoptosis. $\mathrm{PI} 3 \mathrm{Ks}$ in combination with protein kinase $\mathrm{B}(A K T)$ and $m T O R$ (mammalian target of rapamycin) also known as the $P I 3 K / A K T$ signalling pathway is crucial to many aspects of cell growth/survival and apoptosis, and subsequently cancer [45-47]. PI3K are heterodimers consisting of a p 85 regulatory subunit and a p110 catalytic subunit. P85 is encoded by PI3KR1 (p85 $)$ and PI3KR2 (p85 $\beta$ ) forming the heterodimers. Mutations of PIK3RI and/or $P I K 3 R 2$ are also found in cancer cells resulting in the altered expression of PI3K [48, 49]. Therefore, we studied the epigenetic regulation of $P I K 3 R 2 / p 85 \beta$ expression, which was significantly upregulated for MWCNT-treated cells (FDR corrected $P<0.001$ ) though no significant difference in DNA methylation values between exposed and control samples were observed. Higher expression $P I K 3 R 2$ has been observed in lung squamous cell carcinoma as compared to normal tissue [50]. Since, increase in $P I K 3 R 2$ expression has been reported in several cancers $[48,51]$ we believe the findings of MWCNT are of considerable significance.

Myosin-1C (MYO1C), another important gene in the $P I 3 K / A K T$ signalling pathway, is known to bind with PIP2 and potentially acts as a tumour suppressor $[52,53]$. MYO1C has also a role in glucose uptake and cell cycle progression. In our study, the expression of $M Y O 1 C$ was significantly altered for MWCNT (FDR corrected $P=0.015$ ), yet no association with promoter methylation was observed. Interestingly, in the study by Oldfors et al., [52] no evident association between reduced MYO1C expression and promoter methylation were observed in endometrial carcinoma.

$M A P 3 K 10$ showed significant change in DNA methylation patterns for MWCNT exposure. MAP $3 K 10$ (MLK2 or MST) is serine/threonine kinase which plays critical role in the JNK signalling cascade, by a series of phosphorylation and is significant in cell proliferation and apoptosis [54]. Significant hypomethylation of CpGs 3, 4 and 5 in the selected promoter sequence was observed for MWCNT $(25 \mu \mathrm{g} / \mathrm{ml})$; however, no significant changes were observed for SWCNT. The changes in methylation were not reflected in the RNA expression data, as only a non-significant increase in expression was observed for MWCNT (1.6-fold, FDR corrected $P=0.121$ ).

Recruitment of acetyltransferases and deacetylase enzymes are a key to an efficient DDR mechanism as well as other critical cellular processes. $H D A C s$ associated with the DDR mechanism are mostly recruited post repair, where it plays key role in chromatin restoration. The role of HDACs in cancer has been clearly established by several studies $[55,56]$. $H D A C 4$, a class IIa $H D A C$, is one of the critical components of the DDR pathway that acts together with p53-binding protein 1 (53BP1) $[57,58]$. We studied RNA expression of $H D A C 4$, but no significant alterations were induced by MWCNT or SWCNT. However, err hypermethylation of CpG1 of the studied sequence was observed, significant for MWCNT treatment concentration $25 \mu \mathrm{g} / \mathrm{ml}$. While the impact of methylation was not observed on the expression, possible adverse outcome cannot be ruled out based on spatial and temporal influence of DNA methylation on gene regulation and expression.

B

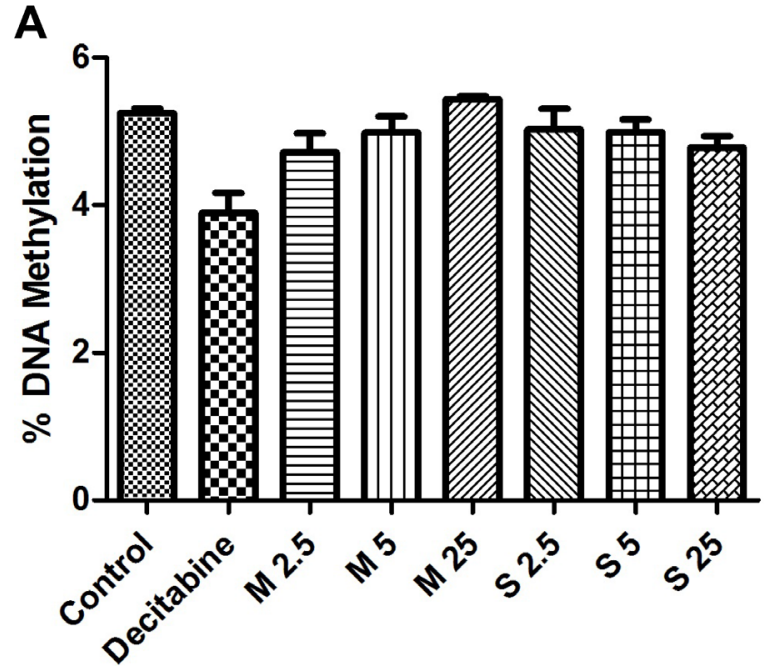

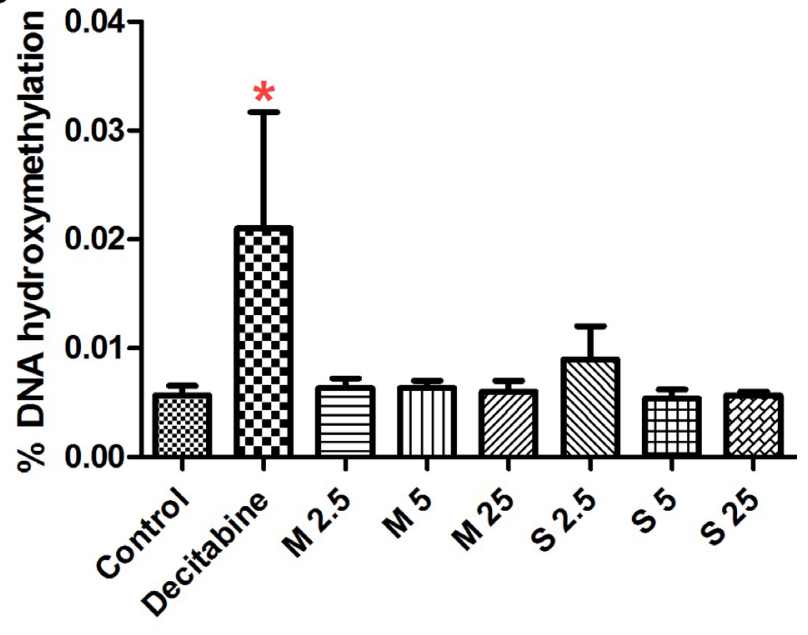

Figure 2: Effect of CNT exposure on global (A) DNA methylation and (B) hydroxy-methylation; numbers followed by M and S represents concentrations $(\mu \mathrm{g} / \mathrm{ml})$ of MWCNT and SWCNT respectively; bars represent mean $\pm \mathrm{SEM} ;{ }^{*} P<0.05$. 
Cellular response to DNA damage also involves series of well synchronized events involving DNA methyltransferases (DNMTs). While DNMTs are key to establishing and maintaining DNA methylation patterns, contributing to chromatin structure and genome stability, evidences have suggested that some of the $D N M T S$, specifically DNMT1 could be directly involved in DDR in methylation independent manner $[59,60]$. Evidence suggests dysregulation of DNMT expression in cancers $[61,62]$. In this study, we investigated promoter methylation and expression of DNMT1 to understand the impact of CNT exposure. We did not observe a significant change in RNA expression, on the contrary a significant hypermethylation of one $\mathrm{CpG}$ site in the promoter sequence was observed for SWCNT treatment.

Transcription factor 3 (TCF3/E2A) is involved in regulation of p21 and PUMA (p53 upregulated modulator of apoptosis), and plays significant role in determining
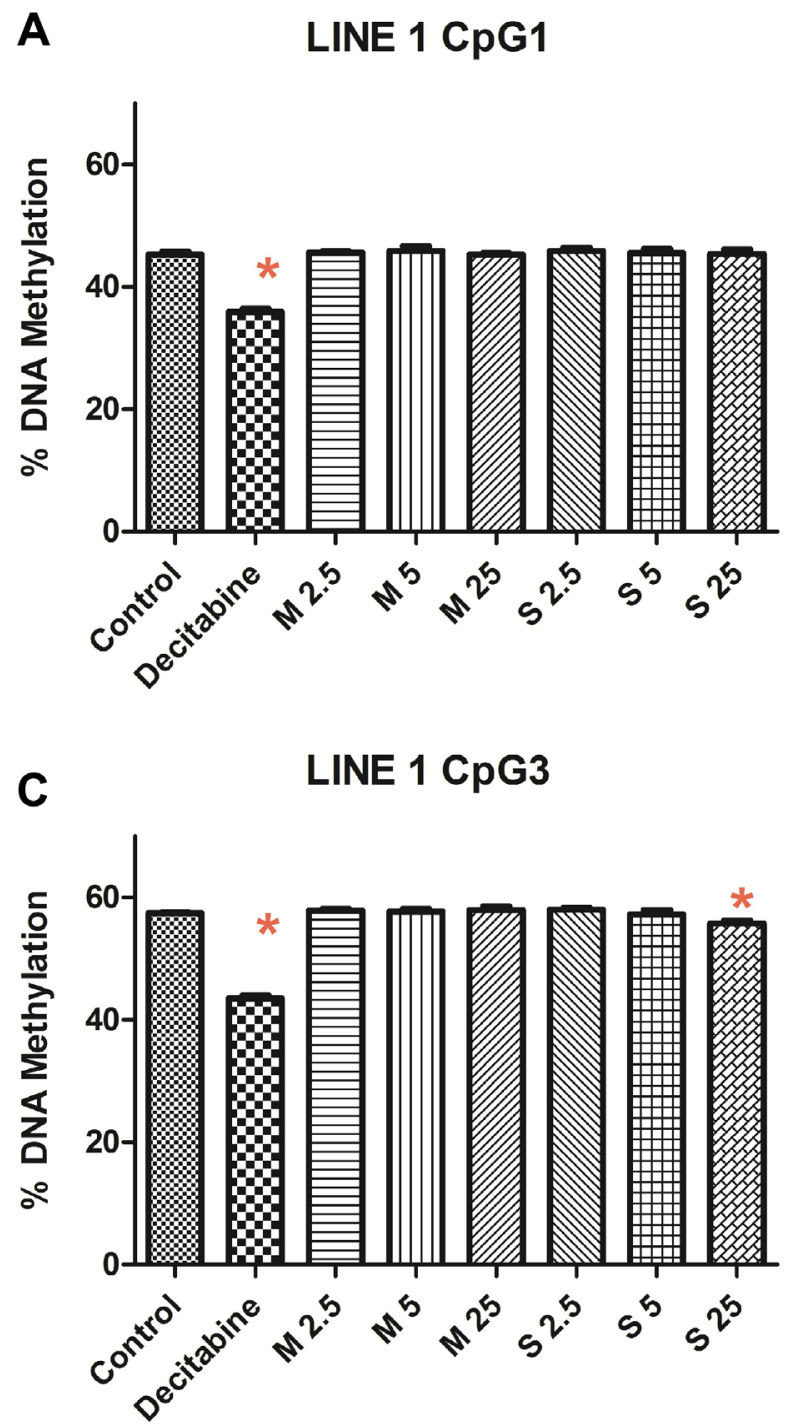

p53 mediated apoptotic response. TCF3 was of additional interest as it was differentially methylated in monocytic cells, as reported in our previous study [28]. While an overall hypomethylation of promoter region was observed for MWCNT $(0.53 \pm 0.10)$ and SWCNT $(0.42 \pm 0.13)$ compared to the negative control $(0.79 \pm 0.52)$, the change was not significant in the present study. The expression of TCF3 however, was significantly altered in MWCNTtreated cells $(P<0.001$ FDR corrected $)$, while it remained mostly unaltered for SWCNT treatment $(P=0.77$, FDR corrected). Upregulation of TCF3 expression, associated with promoter hypomethylation is in accordance with previously published literature observed in colorectal cancer [63].

DNA damage may lead to apoptosis either by extrinsic (death receptor) or intrinsic (mitochondria) pathways. While the role of MAPK and TGF-beta signalling pathways are evident for CNT [64], there

\section{B LINE $1 \mathrm{CpG} 2$}
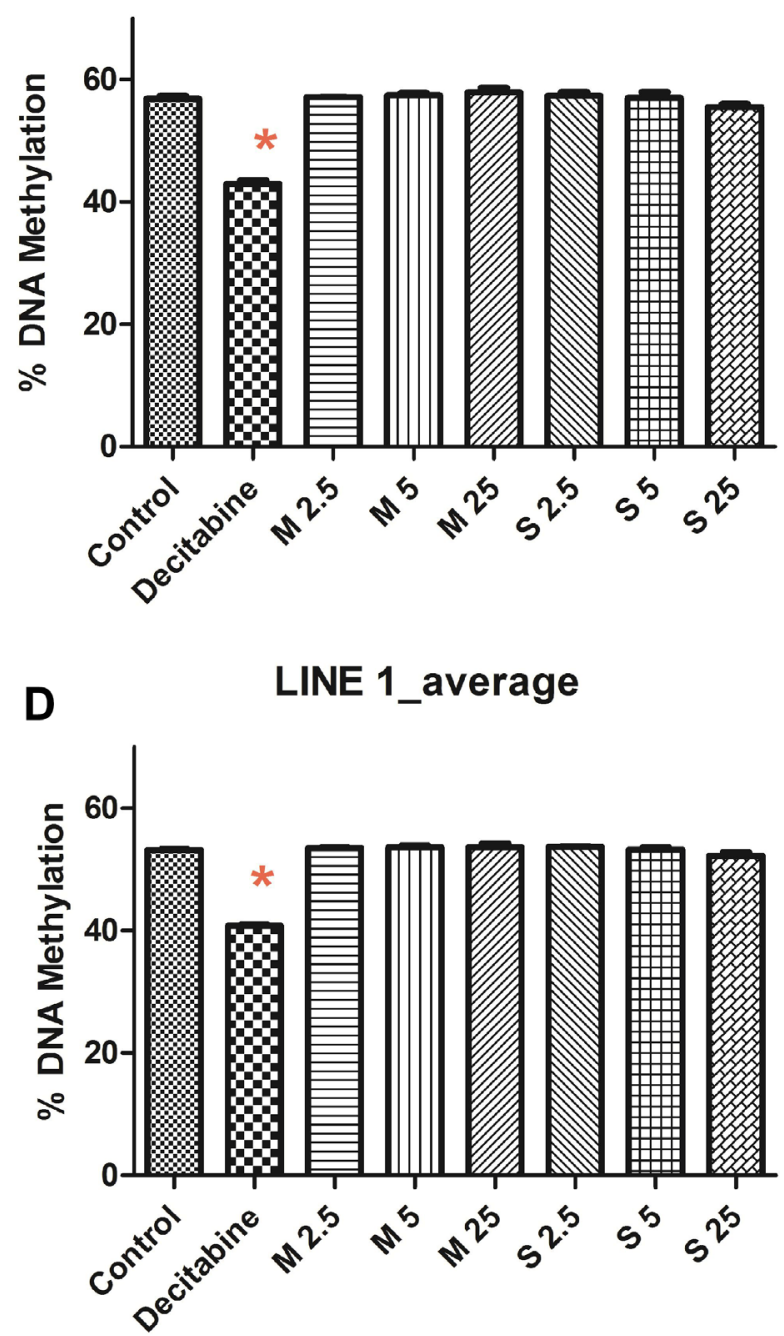

Figure 3: LINE-1 methylation at (A) $\mathrm{CpG}$ position 1, (B) $\mathrm{CpG}$ position 2, (C) $\mathrm{CpG}$ position 3 and (D) average methylation of CpG sites; numbers followed by M and S represents concentrations $(\mu \mathrm{g} / \mathrm{ml})$ of MWCNT and SWCNT respectively; bars represent mean $\pm \mathrm{SEM} ;{ }^{*} P<0.05$. 
is growing evidence of CNT-induced mitochondrial disruption and apoptosis. The intrinsic apoptotic pathway is usually activated by DNA damage and can be activated by caspase 8 . One of the central genes in the BCL2 family is $B C L 2 L 11 / B I M$, which encodes $B C L 2 L 11$, a 'BH3only protein' member of the BCL2 family. In our study, we observed a significant down regulation of $B C L 2 L 11$ $(P<0.001$ FDR corrected) for MWCNTexposure. Hypermethylation of the promoter sequence was observed for all the treatment concentrations of MWCNT and SWCNT, admittedly it was not significant. Lower expression of $B C L 2 L 11$ associated with DNA hypermethylation has been observed in chronic myeloid leukaemia [65]. In another study, hypermethylation of BCL2L11 was observed after exposure to bisphenol A [66]. Fish [67] also observed promoter hyper-methylation $B C L 2 L 11$ in lung tumours.

A
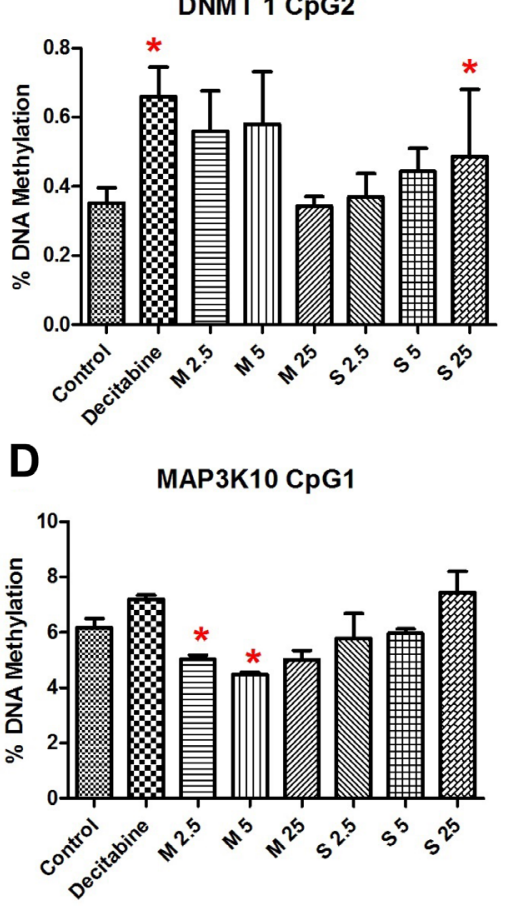

G

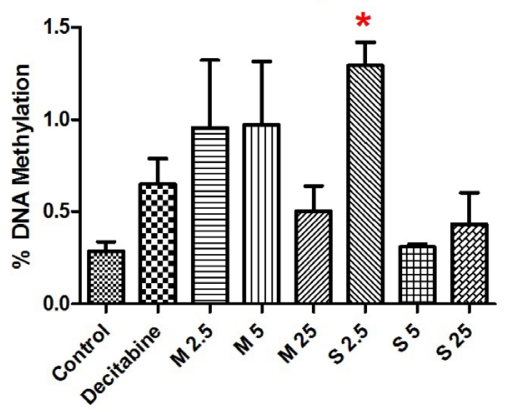

Amplification and dysregulation of FGR family and specifically FGFR 1 has been observed in small cell carcinoma and other forms of cancer [68-70]. In our study, we observed a significant (FDR corrected $P<0.001$ ) upregulation of FGFR 1 expression for MWCNT treatment, which was not associated with DNA methylation of the promoter sequence $(R 2=0.116)$. While a hypomethylation of $\mathrm{CpG}$ positions 1 and 2 were observed for MWCNT, the change was not significant. FGFR1 gene was also found to be significantly hypo- methylated by CNT in our previous study on monocyte cell- THP-1 [28]. In another study, Goldstein et al. [69]. reported overexpression of FGFRI associated with hypomethylation of a $\mathrm{CpG}$ island upstream of exon 1. We also studied the changes in methylation and expression of SKI gene, which plays a critical role in TGF-beta signalling repression [71]. Changes in signalling pathway (TGF- $\beta$, Akt/GSK-3 $\beta$, SNAIL-1) has also been
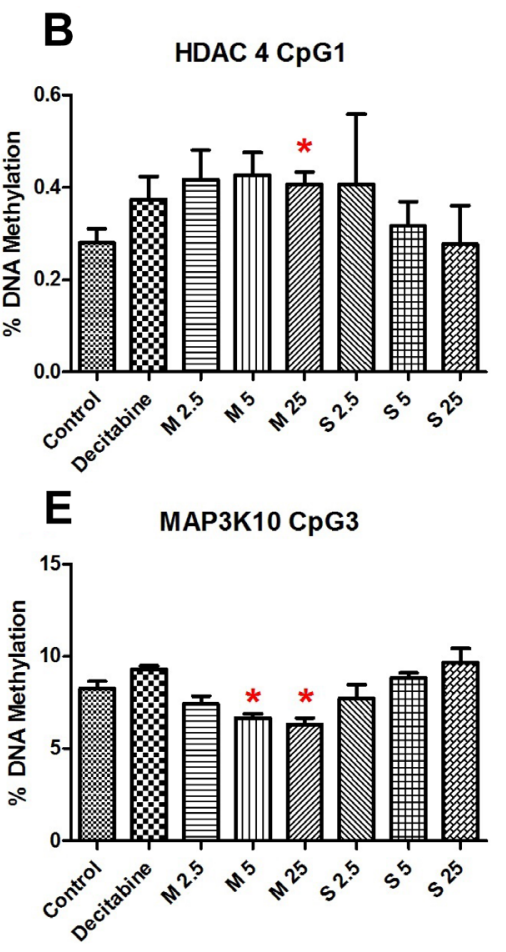
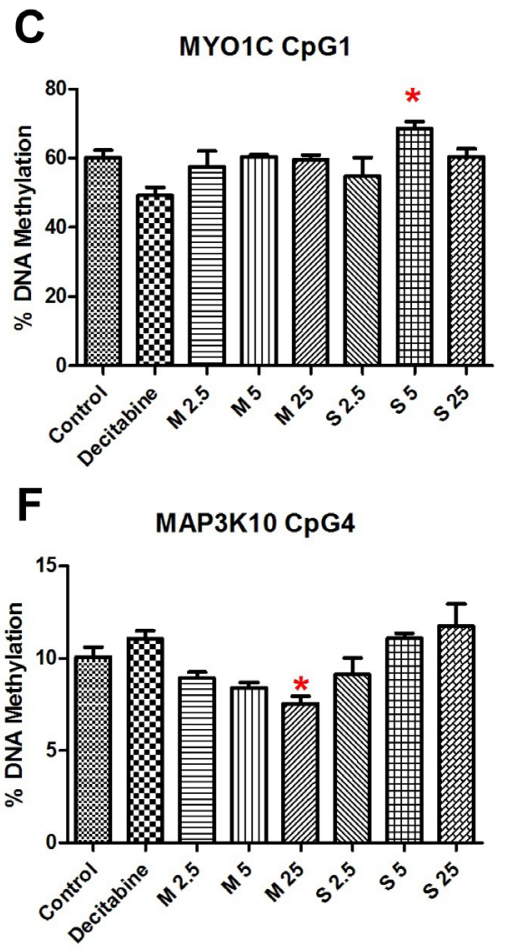

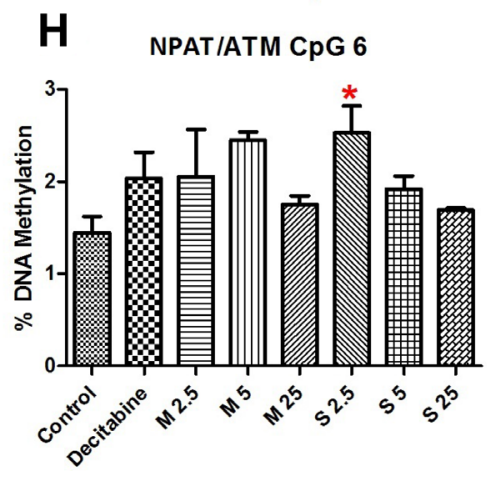

Figure 4: Results showing significant changes in sequence specific methylation of (A) DNMT1 CpG 2, (B) HDAC4 CpG 1, (C) $M Y O 1 C$ CpG 1, (D) MAP3K10 CpG 1, (E) MAP3K10 CpG 3, (F) MAP3K10 CpG 4, (G) NPAT/ATM CpG 4, (H) NPAT/ $A T M \mathrm{CpG} 6$; bars represent mean $\pm \mathrm{SEM} ;{ }^{*} P<0.05$. Numbers followed by $\mathrm{M}$ and $\mathrm{S}$ represents concentrations $(\mu \mathrm{g} / \mathrm{ml})$ of MWCNT and SWCNT respectively. 
reported for BEAS-2B cells [12]. In our study however, methylation of the $\mathrm{CpG}$ sites remained unaffected.

Taken together, in our study, we did not observe any significant changes in level of global DNA methylation. While some sequence specific methylation changes were observed, the changes were relatively small. Some of these changes were found to be associated with changes in RNA expression. Based on literature it is now evident that CNTs may induced epigenetic changes, however the results are not always uniform. In vitro exposure to carbon-based nanoparticles (carbon black, short MWCNTs and SWCNTs) induced global hypermethylation in A549 cells [26], while our previously published studies indicated no changes at global levels $[28,29]$. Differences in global DNA methylation were found to be cell type specific by Chatterjee et al., [23], where MWCNT induced global DNA hypermethylation in HepG2 cells, whereas it induced hypomethylation in BEAS-2B cells. Epigenome wide analysis of methylation in THP-1 cells [28], revealed gene promoter-specific hypomethylation of more than 1000 genes. Our study in 16-HBE cell, also revealed that a large number of genes were hypomethylated at promoter sites after exposure to MWCNT and SWCNT [29]. In the study [29] we observed the changes in methylation to be associated with changes in expression of ATM, SKI, GSTP1, NF1 among others. Epigenome wide study by Sierra et al. [25], also indicated hypomethylation of $755 \mathrm{CpG}$ sites in BEAS-2B cells exposed to MWCNTs. Sierra et al., [25], also reported that these changes were concentration and time dependent, with $\mathrm{CpG}$ sites more differentially hypomethylated at 4 weeks compared to 2 weeks exposure. Relatively fewer studies have investigated the effect of CNT exposure in rodent model. Intra-tracheal administration of CNTs have been shown to induce epigenetic changes in mice lung tissue, where changes in gene promoter methylation was observed for ATM gene [27]. In addition to global DNA hypomethylation, the study by Brown et al.,
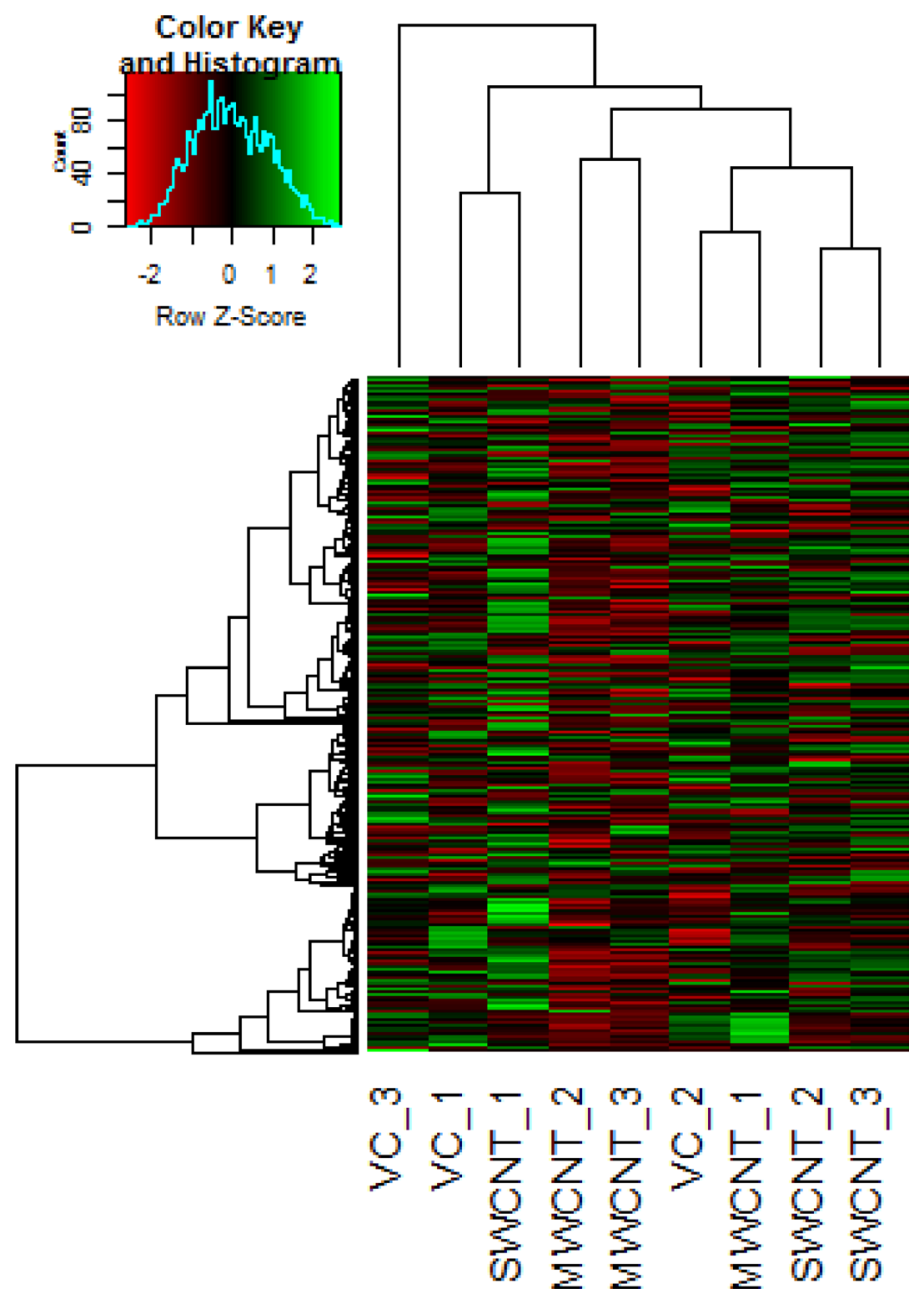

Figure 5: Representative heat map obtained by unsupervised hierarchical clustering of the miRNA expression data; each row represents a miRNA and each column represents a sample. VC_1, VC_2 and VC_3 represent the vehicle control samples, MWCNT_1, MWCNT_2, MWCNT_3 represents multi walled carbon nanotube exposed samples and SWCNT_1, SWCNT_2, SWCNT_3 represents single walled carbon nanotube exposed samples. miRNA clustering tree is shown on the left, and the sample clustering tree appears at the top. The colour scale shown at the top illustrates the relative expression level of a miRNA in the certain slide: green, high relative expression level; red, low relative expression level. 
[22] in C57BL/6 mice also reported promoter specific methylation of IFN- $\gamma$ and TNF- $\alpha$ genes in the lung tissue of MWCNT exposed mice. It may be important to note, the results of our present study are consistent with our study in human population [17], where sequence specific DNA methylation changes (DNMT1, ATM, SKI, HDAC4) were observed in MWCNT exposed workers, despite no changes in global DNA methylation.

As stated earlier, the genes for the present were selected based on their importance in several cellular pathways including DDR response and epigenetic regulation, among others. Taken together changes in methylation and/or expression of the selected genes, specifically by MWCNT, would be expected to influence multitude of cellular functions (Figure 6) including "repressing transcription factor binding", "DNA methylation", "intrinsic apoptotic signalling pathway" and "chromatin remodelling". In addition to the genes reported in the present study, associated genes observed from the network (outer ring in Figure 6) included DNMT3B, several members of HDAC (HDAC1, HDAC3, HDAC5, and HDAC9) and Bcl-2 family; which have also been implicated in several diseases including lung cancer. And thus, epigenetic changes and changes in expression of the genes reported in the present study could be expected to have a cascade- effect leading to dysregulation of signalling pathway and cellular response.

In addition to changes in DNA methylation, studying miRNA expression often provides key information on the dysregulation of cellular processes. With several identified human miRNAs and their established role in gene regulation, especially in cancer $[72,73]$ and lung cancer [74]; we investigated changes in miRNA expression in cells exposed to CNTs. We did not observe any significant alteration in the miRNA profile at fold change cut-off of $>2$ and FDR-corrected $p$ values of $<0.05$. Though not significant, some miRNAs, such as hsa-miR-601 was upregulated in MWCNT exposure (Relative Quantification, $R Q=1306.83$ ) while it was downregulated by SWCNT $(R Q=0.01)$. Since, it has been reported that hsa-miR-601 can down-regulate Fas-induced apoptosis pathway and repressing nuclear factor-kappaB $(N F-\kappa B)$ transcription factor in A549 cells [75], it could be of interest. Another miRNA, which was up regulated by SWCNT was hsa-mir-34b $(R Q=1.98)$, but the increase was not significant. Interestingly miR-34 family is associated with p53 network and is believed to be involved in some forms of cancers, and can be correlated with poor survival in smokers suffering from squamous cell carcinoma [74]. However, since the levels of miRNA were

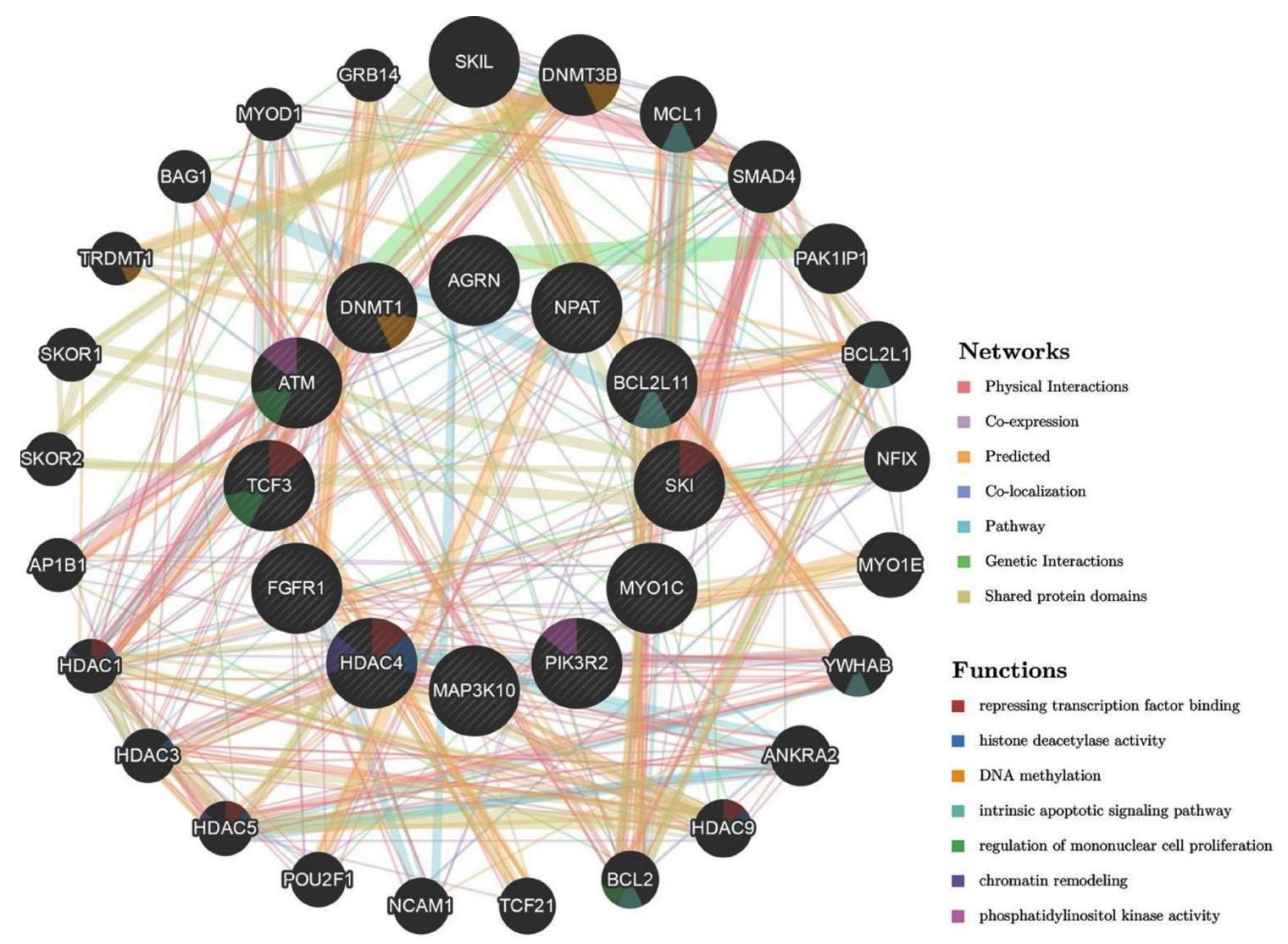

Figure 6: Schematic representation of the interaction network of the studied genes (represented by the circles in the inner ring; HDAC4, TCF3, FGFR1, PIK3R2, MAP3K10, DNMT1, NPAT, ATM, BCL2L11, SKI, AGRN, MYO1C) generated by automatically selected weighting method using GeneMANIA Application version: 3.5.0. A colour code in each of the circle (gene) indicates the associated molecular function. 
not significantly altered and was measured only after 24 $\mathrm{h}$ of exposure it is difficult to comment on the biological implication.

In summary, while the genes studied are not representative of methylation pattern of the whole genome, changes in their methylation and expression certainly provides important evidence of dysregulation of genes involved in critical pathways. MWCNT induced more changes in expression and/or DNA methylation of the studied genes, when compared to SWCNT. No significant changes in miRNA expression were observed for both MWCNT and SWCNT. Given the dynamic nature of these changes (DNA methylation, expression and miRNA), and since all the endpoints were studied at a single time point, it might be important to further study these changes over different time points after exposure.

\section{MATERIALS AND METHODS}

\section{Nanomaterial characterization}

Reference materials were obtained from European Commission JRC (MWCNT; JRC-NM400) and US NIST (SWCNT; NIST-SRM2483). The particles were characterized using TEM for primary size [28]. The protocol from European Union project Engineered Nanoparticle Risk Assessment (ENPRA) was used to prepare dispersion as described earlier [28]. DLS measurements were performed for the different concentrations in the cell culture media, at 1 and $24 \mathrm{~h}$.

\section{Study design and exposure condition}

Dr. Gruenert (University of California, San Francisco) provided $16 \mathrm{HBE}$ human bronchial epithelial cell lines. The cells were cultured in DMEM/F12 supplemented with $5 \%$ of FCS and $1 \%$ of PenicillinStreptomycin (10000 U/ml), L-glutamine (200 mM) and, Amphotericin-B $(250 \mu \mathrm{g} / \mathrm{ml})$, incubated at $37^{\circ} \mathrm{C}$ in a $100 \%$ humidified atmosphere containing $5 \% \mathrm{CO}_{2}$. Cell culture medium was renewed every 2 days and sub-cultured at confluence. Stock of cells was generated and kept in liquid nitrogen to avoid the effect of cell stock/source. Cells from the same stock were grown until passage 4 for epigenetic experiments to avoid influence of cell passage/aging on epigenetic changes. Cells were seeded in wells of plates at density of $2 \times 10^{5}$ cells $/ \mathrm{cm}^{2}$ and allowed to attach for 24 $\mathrm{h}$ to reach $80 \%$ confluence and were exposed for $24 \mathrm{~h}$ to MWCNT and SWCNT. Cells were exposed in duplicates per condition, for three independent experiments.

Our previous experiments, in vitro (in THP-1 cells) [28], in vivo [27] and in human [17] formed the basis of the present study. For the present study, an exposure duration of $24 \mathrm{~h}$ was selected, so that the results could be comparable to that available data on cyto- and genotoxicity assays. Exposure concentrations (2.5, 5 and
$25 \mu \mathrm{g} / \mathrm{ml}$ ) were selected based on our preliminary cytogenotoxicity screening [28]. Global and sequence specific methylation were studied in all the concentrations $(2.5$, 5 and $25 \mu \mathrm{g} / \mathrm{ml}$ ), while miRNA expression and RNA expression were studied for a single concentration (25 $\mu \mathrm{g} / \mathrm{ml})$. Each sample was done in triplicates. Decitabine $(1 \mu \mathrm{M})$ was used as a positive control for the experiment. DNA, RNA and miRNA were extracted using AllPrep DNA/RNA/miRNA Universal Kit (QIAGEN, Belgium). At the onset, global DNA hydroxymethylation was evaluated. Subsequently, a set of twelve differentially expressed genes were selected from a RNA-sequencing (RNA-seq) data. The differentially expressed genes were also studied for sequence-specific methylation changes. Additionally, miRNA expression was studied in the exposed cells.

\section{Global DNA methylation-LC/MS/MS}

Global DNA methylation and hydroxymethylation was evaluated using LC-MS/MS based method described earlier [76, 77], that allows simultaneous detection of 2'-deoxycytidine (dC), 5-methyl-2'-deoxycytidine (5-mC), and 5-hydroxymethyl-2'-deoxycytidine (5-hmC). The results were expressed as \% DNA methylation calculated as $5-\mathrm{mdC} /(5-\mathrm{mdC}+5-\mathrm{OHmdC}+\mathrm{dC})$, and \% DNA hydroxy-methylation, calculated as $5-\mathrm{OHmdC} /(5-\mathrm{mdC}+$ 5-OHmdC $+\mathrm{dC}$ ).

\section{RNA expression and sequence specific methylation}

Results of differential expression of the genes used for pyrosequencing was extracted from the data set obtained from RNA sequencing. RNA sequencing was performed on a HiSeq2000 (Illumina) as previously described [78]. Briefly, RNA libraries were created using the Illumina TruSeq RNA sample preparation kit V2 according to the manufacturer's instructions and sequencing reads were mapped to the human transcriptome and reference genome (GRCh37.65/hg19) by using TopHat 2.014 and Bowtie 2.0. Differential expression between the different exposures was calculated by using EdgeR16. Detailed analysis of the RNA sequencing dataset will be published elsewhere after detailed analysis of gene ontology, pathway analysis and gene functional classification analysis. For the present study however, data for 12 functionally important genes were used to investigate association with sequence specific methylation.

Sequence specific methylation of repetitive element (LINE-1) and gene promoters (SKI, DNMT 1, HDAC 4, NPAT/ATM, BCL2L11, MAP3K10, PIK3R2, MYO1C, $T C F 3, F G F R$ 1, $A G R N$ ) were analyzed using bisulfite pyrosequencing, as described previously [34]. In addition to RNA sequencing results, we obtained the present set 
of genes based on our preliminary experiments in vitro (in THP-1 cells, $16 \mathrm{HBE}$ ) [28, 29], in vivo [27] and human [17]. The set of genes for the present study have critical function in the pathways associated with DNA damage repair response. Bisulfite converted genomic DNA was amplified using Qiagen proprietary PCR primers (Supplementary Table 1, additional sequence information in Supplementary Figure 1), subsequently immobilized onto streptavidin sepharose beads and sequenced using the PyroMark Q24 (Qiagen). The results were analyzed using the PyroMark analysis 2.0.7 software (Build 3, Qiagen). Technical variability six samples (3-negative control and 3 - positive control) were selected for technical variation analysis for some of the randomly selected genes and have been provided in the supplementary file (Supplementary Figure 2).

\section{miRNA expression}

MiRNA profiling was performed with the TaqMan $^{\circledR}$ Array Human MicroRNA panel. Briefly, extracted RNA was reverse transcribed, followed by preamplification. The pre-amplified products were loaded onto the TaqMan ${ }^{\circledR}$ panel and run on the QuantStudio $12 \mathrm{~K}$ Flex system. Data analysis was performed using DataAssist v3.01. We selected only those samples with detectable $\mathrm{Ct}$ values for all the replicates/concentrations, with average $\mathrm{Ct}$ values $<35$. Global normalization was performed on the data set. Mean relative quantity (RQ) was calculated and miRNAs differentially expressed between groups were defined as those with $>2$ - fold change and $P<0.05$ (two tailed Student's $t$-test), followed by adjustment using the false discovery rate (FDR) correction.

\section{Statistical analysis}

For the results of global DNA methylation and hydroxymethylation and sequence-specific methylation, statistical analysis was performed using GraphPad Prism 5.0 (GraphPad Software, Inc.). Statistical significance using two-tailed unpaired Student's $t$-test with $P<0.05$ was considered significant.

\section{CONFLICTS OF INTEREST}

The authors do not have any conflicts of interest.

\section{FUNDING}

Manosij Ghosh is the recipient of a European Respiratory Society RESPIRE postdoctoral fellowship (RESPIRE2 - 2014-7310). DÖ would like to acknowledge financial assistance to Stichting Tegen Kanker (agreement no: 2012-218, project no: 3M150270).

\section{REFERENCES}

1. Lam CW, James JT, McCluskey R, Hunter RL. Pulmonary Toxicity of Single-Wall Carbon Nanotubes in Mice 7 and 90 Days After Intratracheal Instillation. Toxicological Sciences. 2003; 77:126-34. https://doi.org/10.1093/toxsci/ kfg243.

2. Sayes CM, Liang F, Hudson JL, Mendez J, Guo W, Beach JM, Moore VC, Doyle CD, West JL, Billups WE, Ausman KD, Colvin VL. Functionalization density dependence of single-walled carbon nanotubes cytotoxicity in vitro. Toxicology Letters. 2006; 161:135-42. https://doi. org/10.1016/j.toxlet.2005.08.011.

3. Davoren M, Herzog E, Casey A, Cottineau B, Chambers $\mathrm{G}$, Byrne HJ, Lyng FM. In vitro toxicity evaluation of single walled carbon nanotubes on human A549 lung cells. Toxicology in Vitro. 2007; 21:438-48. https://doi. org/10.1016/j.tiv.2006.10.007.

4. Kato T, Totsuka Y, Ishino K, Matsumoto Y, Tada Y, Nakae D, Goto S, Masuda S, Ogo S, Kawanishi M, Yagi T, Matsuda T, Watanabe M, et al. Genotoxicity of multi-walled carbon nanotubes in both in vitro and in vivo assay systems. Nanotoxicology. 2013; 7:452-61. https://doi.org/10.3109/1 7435390.2012.674571.

5. Sargent LM, Porter DW, Staska LM, Hubbs AF, Lowry DT, Battelli L, Siegrist KJ, Kashon ML, Mercer RR, Bauer AK, Chen BT, Salisbury JL, Frazer D, et al. Promotion of lung adenocarcinoma following inhalation exposure to multiwalled carbon nanotubes. Particle and Fibre Toxicology. 2014; 11:3. https://doi.org/10.1186/1743-8977-11-3.

6. Bayat N, Lopes VR, Schölermann J, Jensen LD, Cristobal $\mathrm{S}$. Vascular toxicity of ultra-small $\mathrm{TiO} 2$ nanoparticles and single walled carbon nanotubes in vitro and in vivo. Biomaterials. 2015; 63:1-13. https://doi.org/10.1016/j. biomaterials.2015.05.044.

7. Xu C, Liu Q, Liu H, Zhang C, Shao W, Gu A. Toxicological assessment of multi-walled carbon nanotubes in vitro: potential mitochondria effects on male reproductive cells. Oncotarget. 2016; 7:39270-8. https://doi.org/10.18632/ oncotarget.9689.

8. Manna SK, Sarkar S, Barr J, Wise K, Barrera EV, Jejelowo O, Rice-Ficht AC, Ramesh GT. Single-Walled Carbon Nanotube Induces Oxidative Stress and Activates Nuclear Transcription Factor- $\kappa \mathrm{B}$ in Human Keratinocytes. Nano Lett. 2005; 5:1676-84. https://doi.org/10.1021/ NL0507966.

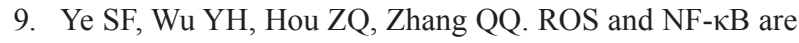
involved in upregulation of IL-8 in A549 cells exposed to multi-walled carbon nanotubes. Biochemical and Biophysical Research Communications. 2009; 379:643648. https://doi.org/10.1016/J.BBRC.2008.12.137.

10. Ravichandran P, Baluchamy S, Sadanandan B, Gopikrishnan R, Biradar S, Ramesh V, Hall JC, Ramesh GT. Multiwalled carbon nanotubes activate NF- $\kappa \mathrm{B}$ and AP-1 signaling pathways to induce apoptosis in rat lung epithelial cells. 
Apoptosis. 2010; 15:1507-16. https://doi.org/10.1007/ s10495-010-0532-6.

11. Dinicola S, Masiello MG, Proietti S, Coluccia P, Fabrizi G, Palombo A, Micciulla F, Bistarelli S, Ricci G, Catizone A, Toma G, Bizzarri M, Bellucci S, et al. Multiwalled carbon nanotube buckypaper induces cell cycle arrest and apoptosis in human leukemia cell lines through modulation of AKT and MAPK signaling pathways. Toxicology in Vitro. 2015; 29:1298-308. https://doi.org/10.1016/j.tiv.2015.05.006.

12. Polimeni M, Gulino GR, Gazzano E, Kopecka J, Marucco A, Fenoglio I, Cesano F, Campagnolo L, Magrini A, Pietroiusti A, Ghigo D, Aldieri E. Multi-walled carbon nanotubes directly induce epithelial-mesenchymal transition in human bronchial epithelial cells via the TGF- $\beta$-mediated Akt/GSK-3 $\beta /$ SNAIL-1 signalling pathway. Particle and Fibre Toxicology. 2015; 13:27. https://oi.org/10.1186/s12989-016-0138-4.

13. Vietti G, Ibouraadaten S, Palmai-Pallag M, Yakoub Y, Bailly C, Fenoglio I, Marbaix E, Lison D, Brule S, Pietroiusti A, Ghigo D, Aldieri E, Stone S, et al. Towards predicting the lung fibrogenic activity of nanomaterials: experimental validation of an in vitro fibroblast proliferation assay. Particle and Fibre Toxicology. 2013; 10:52. https://doi. org/10.1186/1743-8977-10-52.

14. Shvedova AA, Yanamala N, Kisin ER, Khailullin TO, Birch ME, Fatkhutdinova LM, Nurkiewicz T. Integrated Analysis of Dysregulated ncRNA and mRNA Expression Profiles in Humans Exposed to Carbon Nanotubes. PLoS One. 2016; 11:e0150628. https://doi.org/10.1371/journal. pone. 0150628 .

15. Fatkhutdinova LM, Khaliullin TO, Vasil'yeva OL, Zalyalov RR, Mustafin IG, Kisin ER, Birch ME, Yanamala N, Shvedova AA. Fibrosis biomarkers in workers exposed to MWCNTs. Toxicology and Applied Pharmacology. 2016; 299:125-31. https://doi.org/10.1016/j.taap.2016.02.016.

16. Vlaanderen J, Pronk A, Rothman N, Hildesheim A, Silverman D, Hosgood HD, Spaan S, Kuijpers E, Godderis L, Hoet P, Lan Q, Vermeulen R. A cross-sectional study of changes in markers of immunological effects and lung health due to exposure to multi-walled carbon nanotubes. Nanotoxicology. 2017; 11:395-404. https://doi.org/10.108 0/17435390.2017.1308031.

17. Ghosh M, Öner D, Poels K, Tabish AM, Vlaanderen J, Pronk A, Kuijpers E, Lan Q, Vermeulen R, Bekaert B, Hoet $\mathrm{PH}$, Godderis L. Changes in DNA methylation induced by multi-walled carbon nanotube exposure in the workplace. Nanotoxicology. 2017; 11:1195-1210. https://doi.org/10.1 080/17435390.2017.1406169.

18. Baylin SB, Esteller M, Rountree MR, Bachman KE, Schuebel K, Herman JG. Aberrant patterns of DNA methylation, chromatin formation and gene expression in cancer. Human Molecular Genetics. 2001; 10:687-92. https://doi.org/10.1093/hmg/10.7.687.

19. Das PM, Singal R. DNA methylation and cancer. Journal of Clinical Oncology. 2004; 22:4632-42. https://doi. org/10.1200/JCO.2004.07.151.
20. Brock M, Hooker CM, Ota-Machida E, Han Y, Guo M, Ames S, Glöckner S, Piantadosi S, Gabrielson E, Pridham G, Pelosky K, Belinsky SA, Yang SC, et al. DNA Methylation Markers and Early Recurrence in Stage I Lung Cancer. The New England Journal of Medicine. 2008; 358:1118-28. https://doi.org/10.1056/NEJMoa0706550.

21. Coppedè F. Epigenetic biomarkers of colorectal cancer: Focus on DNA methylation. Cancer Letters. 2014; 342:23847. https://doi.org/10.1016/j.canlet.2011.12.030.

22. Brown TA, Lee JW, Holian A, Porter V, Fredriksen H, Kim $\mathrm{M}$, Cho YH. Alterations in DNA methylation corresponding with lung inflammation and as a biomarker for disease development after MWCNT exposure. Nanotoxicology. 2016; 10:453-61. https://doi.org/10.3109/17435390.2015. 1078852.

23. Chatterjee N, Yang J, Kim S, Joo SW, Choi J. Diameter size and aspect ratio as critical determinants of uptake, stress response, global metabolomics and epigenetic alterations in multi-wall carbon nanotubes. Carbon. 2016; 108:529-540. https://doi.org/10.1016/J.CARBON.2016.07.031.

24. Chatterjee N, Yang J, Yoon D, Kim S, Joo SW, Choi J. Differential crosstalk between global DNA methylation and metabolomics associated with cell type specific stress response by pristine and functionalized MWCNT. Biomaterials. 2017; 115:167-80. https://doi.org/10.1016/j. biomaterials.2016.11.005.

25. Sierra MI, Rubio L, Bayón GF, Cobo I, Menendez P, Morales P, Mangas C, Urdinguio RG, Lopez V, Valdes A, Vales G, Marcos R, Torrecillas R, et al. DNA methylation changes in human lung epithelia cells exposed to multiwalled carbon nanotubes. Nanotoxicology. 2017; 11:857870. https://doi.org/10.1080/17435390.2017.1371350.

26. Li J, Tian M, Cui L, Dwyer J, Fullwood NJ, Shen H, Martin FL. Low-dose carbon-based nanoparticle-induced effects in A549 lung cells determined by biospectroscopy are associated with increases in genomic methylation. Scientific Reports. 2016; 6:20207. https://doi.org/10.1038/srep20207.

27. Tabish AM, Poels K, Byun HM, Luyts K, Baccarelli AA, Martens J, Kerkhofs S, Seys S, Hoet P, Godderis L. Changes in DNA Methylation in Mouse Lungs after a Single Intra-Tracheal Administration of Nanomaterials. PLoS One. 2017; 12:e0169886. https://doi.org/10.1371/ journal.pone.0169886.

28. Öner D, Moisse M, Ghosh M, Duca RC, Poels K, Luyts K, Putzeys E, Cokic SM, Landuyt K, Vanoirbeek J, Lambrechts D, Godderis L, Hoet PH. Epigenetic effects of carbon nanotubes in human monocytic cells. Mutagenesis. 2017; 32:181-91. https://doi.org/10.1093/mutage/gew053.

29. Öner D, Ghosh M, Bové H, Moisse M, Boeckx B, Duca RC, Poels K, Luyts K, Putzeys E, Van Landuydt K, Vanoirbeek JA, Ameloot M, Lambrechts D, et al. Differences in MWCNT- and SWCNT-induced DNA methylation alterations in association with the nuclear deposition. Particle and Fibre Toxicology. 2018; 15:11. https://doi. org/10.1186/s12989-018-0244-6. 
30. Ting Hsiung D, Marsit CJ, Houseman EA, Eddy K, Furniss CS, McClean MD, Kelsey KT. Global DNA Methylation Level in Whole Blood as a Biomarker in Head and Neck Squamous Cell Carcinoma. Cancer Epidemiology and Prevention Biomarkers. 2007; 16.

31. Chouliaras L, Mastroeni D, Delvaux E, Grover A, Kenis G, Hof PR, Steinbusch HW, Coleman PD, Rutten BP, van den Hove DL. Consistent decrease in global DNA methylation and hydroxymethylation in the hippocampus of Alzheimer's disease patients. Neurobiology of Aging. 2013; 34:2091-9. https://doi.org/10.1016/j.neurobiolaging.2013.02.021.

32. Ficz G, Gribben JG. Loss of 5-hydroxymethylcytosine in cancer: Cause or consequence? Genomics. 2014; 104:3527. https://doi.org/10.1016/j.ygeno.2014.08.017.

33. Jeschke J, Collignon E, Fuks F. Portraits of TET-mediated DNA hydroxymethylation in cancer. Current Opinion in Genetics \& Development. 2016; 36:16-26. https://doi. org/10.1016/j.gde.2016.01.004.

34. Tabish AM, Baccarelli AA, Godderis L, Barrow TM, Hoet P, Byun HM. Assessment of Changes in Global DNA Methylation Levels by Pyrosequencing ${ }^{\circledR}$ of Repetitive Elements. Methods Mol Biol. 2015; 1315:201-7.

35. Chalitchagorn K, Shuangshoti S, Hourpai N, Kongruttanachok N, Tangkijvanich P, Thong-ngam D, Voravud N, Sriuranpong V, Mutirangura A. Distinctive pattern of LINE-1 methylation level in normal tissues and the association with carcinogenesis. Oncogene. 2004; 23:8841-6. https://doi.org/10.1038/sj.onc.1208137.

36. Liao LM, Brennan P, Bemmel DM, Zaridze D, Matveev V, Janout V, Kollarova H, Bencko V, Navratilova M, Szeszenia-Dabrowska N, Mates D, Rothman N, Boffetta P, et al. LINE-1 Methylation Levels in Leukocyte DNA and Risk of Renal Cell Cancer. PLoS One. 2011; 6:e27361. https://doi.org/10.1371/journal.pone.0027361.

37. Kitkumthorn N, Tuangsintanakul T, Rattanatanyong $P$, Tiwawech D, Mutirangura A. LINE-1 methylation in the peripheral blood mononuclear cells of cancer patients. Clinica Chimica Acta. 2012; 413:869-74. https://doi. org/10.1016/j.cca.2012.01.024.

38. Foroughizadeh M, Mozdarani H, Majidzadeh-A K, Kaviani A. Variation of ATM Gene Expression in Peripheral Blood Cells of Sporadic Breast Carcinomas in Iranian Patients. Avicenna Journal of Medical Biotechnology. 2012; 4:95101.

39. Jianlin L, Jiliang H, Lifen J, Wei Z, Zhijian C, Shijie C, Shijie X. Variation of ATM protein expression in response to irradiation of lymphocytes in lung cancer patients and controls. Toxicology. 2006; 224:138-46. https://doi. org/10.1016/j.tox.2006.04.040.

40. Helgason H, Rafnar T, Olafsdottir HS, Jonasson JG, Sigurdsson A, Stacey SN, Jonasdottir A, Tryggvadottir L, Alexiusdottir K, Haraldsson A, Roux L, Gudmundsson J, Johannsdottir H, et al. Loss-of-function variants in ATM confer risk of gastric cancer. Nature Genetics. 2015; 47:906-10. https://doi.org/10.1038/ng.3342.
41. Kim W, Vo QN, Shrivastav M, Lataxes TA, Brown KD. Aberrant methylation of the ATM promoter correlates with increased radiosensitivity in a human colorectal tumor cell line. Oncogene. 2002; 21:3864-71. https://doi.org/10.1038/ sj.onc. 1205485 .

42. Vo QN, Kim WJ, Cvitanovic L, Boudreau DA, Ginzinger DG, Brown KD. The ATM gene is a target for epigenetic silencing in locally advanced breast cancer. Oncogene. 2004; 23:9432-7. https://doi.org/10.1038/sj.onc.1208092.

43. Treilleux I, Chapot B, Goddard S, Pisani P, Angèle S, Hall J. The molecular causes of low ATM protein expression in breast carcinoma; promoter methylation and levels of the catalytic subunit of DNA-dependent protein kinase. Histopathology. 2007; 51:63-9. https://doi.org/10.1111/ j.1365-2559.2007.02726.x.

44. Mehdipour P, Karami F, Javan F, Mehrazin M. Linking ATM Promoter Methylation to Cell Cycle Protein Expression in Brain Tumor Patients: Cellular Molecular Triangle Correlation in ATM Territory. Molecular Neurobiology. 2015; 52:293-302. https://doi.org/10.1007/s12035-0148864-9.

45. Lui VWY, Hedberg ML, Li H, Vangara BS, Pendleton K, Zeng Y, Lu Y, Zhang Q, Du Y, Gilbert BR, Freilino M, Sauerwein S, Peyser ND, et al. Frequent Mutation of the PI3K Pathway in Head and Neck Cancer Defines Predictive Biomarkers. Cancer Discovery. 2013; 3.

46. Fruman DA, Rommel C. PI3K and cancer: lessons, challenges and opportunities. Nature Reviews Drug Discovery. 2014; 13:140-56. https://doi.org/10.1038/ $\operatorname{nrd4204.}$

47. Saldanha SN, Tollefsbol TO. Pathway modulations and epigenetic alterations in ovarian tumorbiogenesis. Journal of Cellular Physiology. 2014; 229:393-406. https://doi. org/10.1002/jcp.24466.

48. Cheung LWT, Hennessy BT, Li J, Yu S, Myers AP, Djordjevic B, Lu Y, Stemke-Hale K, Dyer MD, Zhang F, $\mathrm{Ju}$ Z, Cantley LC, Scherer SE, et al. High Frequency of PIK3R1 and PIK3R2 Mutations in Endometrial Cancer Elucidates a Novel Mechanism for Regulation of PTEN Protein Stability. Cancer Discovery. 2011; 1.

49. Herrero-Gonzalez S, Cristofano A. New Routes to Old Places: PIK3R1 and PIK3R2 Join PIK3CA and PTEN as Endometrial Cancer Genes. Cancer Discovery. 2011; 1.

50. Vallejo-Díaz J, Olazabal-Morán M, Cariaga-Martínez AE, Pajares MJ, Flores JM, Pio R, Montuenga LM, Carrera AC. Targeted depletion of PIK3R2 induces regression of lung squamous cell carcinoma. Oncotarget. 2016; 7:85063-78. https://doi.org/10.18632/oncotarget.13195.

51. Thorpe LM, Yuzugullu H, Zhao JJ. PI3K in cancer: divergent roles of isoforms, modes of activation and therapeutic targeting. Nature Reviews Cancer. 2014; 15:724. https://doi.org/10.1038/nrc3860.

52. Hedberg Oldfors C, Dios DG, Linder A, Visuttijai K, Samuelson E, Karlsson S, Nilsson S, Behboudi A. Analysis 
of an independent tumor suppressor locus telomeric to Tp53 suggested Inpp5k and Myo1c as novel tumor suppressor gene candidates in this region. BMC Genetics. 2015; 16:80. https://doi.org/10.1186/s12863-015-0238-4.

53. Visuttijai K, Pettersson J, Mehrbani Azar Y, Bout I, Örndal C, Marcickiewicz J, Nilsson S, Hörnquist M, Olsson B, Ejeskär K, Behboudi A. Lowered Expression of Tumor Suppressor Candidate MYO1C Stimulates Cell Proliferation, Suppresses Cell Adhesion and Activates AKT. PLoS One. 2016; 11:e0164063. https://doi.org/10.1371/ journal.pone.0164063.

54. Pritchard AL, Hayward NK. Molecular Pathways: MitogenActivated Protein Kinase Pathway Mutations and Drug Resistance. Clinical Cancer Research. 2013; 19.

55. Ropero S, Esteller M. The role of histone deacetylases (HDACs) in human cancer. Molecular Oncology. 2007; 1:19-25. https://doi.org/10.1016/j.molonc.2007.01.001.

56. Kang ZH, Wang CY, Zhang WL, Zhang JT, Yuan CH, Zhao PW, Lin YY, Hong S, Li CY, Wang L. Histone Deacetylase HDAC4 Promotes Gastric Cancer SGC-7901 Cells Progression via p21 Repression. PLoS One. 2014; 9:e98894. https://doi.org/10.1371/journal.pone.0098894.

57. Kao GD, McKenna WG, Guenther MG, Muschel RJ, Lazar MA, Yen TJ. Histone deacetylase 4 interacts with 53BP1 to mediate the DNA damage response. The Journal of Cell Biology. 2003; 160.

58. Basile V, Mantovani R, Imbriano C. DNA damage promotes histone deacetylase 4 nuclear localization and repression of G2/M promoters, via p53 C-terminal lysines. The Journal of Biological Chemistry. 2006; 281:2347-57. https://doi. org/10.1074/jbc.M507712200.

59. Mortusewicz O, Schermelleh L, Walter J, Cardoso MC, Leonhardt H. Recruitment of DNA methyltransferase I to DNA repair sites. Proceedings of the National Academy of Sciences of the United States of America. 2005; 102:89059. https://doi.org/10.1073/pnas.0501034102.

60. Jin B, Robertson KD. DNA Methyltransferases, DNA Damage Repair, and Cancer. Exp Med Biol. 2013; 754:3-29.

61. Suzuki M, Sunaga N, Shames DS, Toyooka S, Gazdar AF, Minna JD. RNA Interference-Mediated Knockdown of DNA Methyltransferase 1 Leads to Promoter Demethylation and Gene Re-Expression in Human Lung and Breast Cancer Cells. Cancer Research. 2004; 64.

62. Pathania R, Ramachandran S, Elangovan S, Padia R, Yang P, Cinghu S, Veeranan-Karmegam R, Arjunan P, GnanaPrakasam JP, Sadanand F, Pei L, Chang CS, Choi JH, et al. DNMT1 is essential for mammary and cancer stem cell maintenance and tumorigenesis. Nature Communications. 2015; 6:6910. https://doi.org/10.1038/ncomms7910.

63. Li C, Cai S, Wang X, Jiang Z, Atkins J. HypomethylationAssociated Up-Regulation of TCF3 Expression and Recurrence in Stage II and III Colorectal Cancer. PLoS One. 2014; 9:e112005. https://doi.org/10.1371/journal. pone. 0112005 .
64. Dong J, Ma Q. Suppression of basal and carbon nanotubeinduced oxidative stress, inflammation and fibrosis in mouse lungs by Nrf2. Nanotoxicology. 2016; 10:699-709. https://doi.org/10.3109/17435390.2015.1110758.

65. Leo E, Mancini M, Aluigi M, Castagnetti F, Martinelli G, Barbieri E, Santucci MA. DNA hypermethylation promotes the low expression of pro-apoptotic BCL2L11 associated with BCR - ABL1 fusion gene of chronic myeloid leukaemia. British Journal of Haematology. 2012; 159:3736. https://doi.org/10.1111/bjh.12023.

66. Fernandez SV, Huang Y, Snider KE, Zhou Y, Pogash TJ, Russo J. Expression and DNA methylation changes in human breast epithelial cells after bisphenol A exposure. International Journal of Oncology. 2012; 41:369-77.

67. Fish TJ, Benninghoff AD. DNA methylation in lung tissues of mouse offspring exposed in utero to polycyclic aromatic hydrocarbons. Food and Chemical Toxicology. 2017; 109:703-713. https://doi.org/10.1016/j.fct.2017.04.047.

68. Giri D, Ropiquet F, Ittmann M. Alterations in Expression of Basic Fibroblast Growth Factor (FGF) 2 and Its Receptor FGFR-1 in Human Prostate Cancer. Clinical Cancer Research. 1999; 5 .

69. Goldstein M, Meller I, Orr-Urtreger A. FGFR1 overexpression in primary rhabdomyosarcoma tumors is associated with hypomethylation of a 5' $\mathrm{CpG}$ Island and abnormal expression of the AKT1, NOG, and BMP4 genes. Genes, Chromosomes \& Cancer. 2007; 46:1028-38. https:// doi.org/10.1002/gcc.20489.

70. Heist RS, Mino-Kenudson M, Sequist L, Tammireddy S, Morrissey L, Christiani DC, Engelman JA, Iafrate AJ. FGFR1 Amplification in Squamous Cell Carcinoma of The Lung. Journal of Thoracic Oncology. 2012; 7:1775-80. https://doi.org/10.1097/JTO.0b013e31826aed28.

71. Luo K, Stroschein SL, Wang W, Chen D, Martens E, Zhou S, Zhou Q. The Ski oncoprotein interacts with the Smad proteins to repress TGFbeta signaling. Genes \& Development. 1999; 13:2196-206.

72. Volinia S, Calin GA, Liu CG, Ambs S, Cimmino A, Petrocca F, Visone R, Iorio M, Roldo C, Ferracin M, Prueitt RL, Yanaihara N, Lanza G, et al. A microRNA expression signature of human solid tumors defines cancer gene targets. Proceedings of the National Academy of Sciences of the United States of America. 2006; 103:2257-61. https://doi. org/10.1073/pnas.0510565103.

73. Reddy KB. MicroRNA (miRNA) in cancer. Cancer Cell International. 2015; 15:38. https://doi.org/10.1186/s12935015-0185-1.

74. Leidinger P, Keller A, Meese E. MicroRNAs - Important Molecules in Lung Cancer Research. Frontiers in Genetics. 2011; 2:104. https://doi.org/10.3389/fgene.2011.00104.

75. Ohdaira H, Nakagawa H, Yoshida K. Profiling of molecular pathways regulated by microRNA 601. Computational Biology and Chemistry. 2009; 33:429-33. https://doi. org/10.1016/j.compbiolchem.2009.09.003. 
76. Godderis L, Schouteden C, Tabish A, Poels K, Hoet P, Baccarelli AA, Landuyt K. Global Methylation and Hydroxymethylation in DNA from Blood and Saliva in Healthy Volunteers. BioMed Research International. 2015; 2015:845041. https://doi.org/10.1155/2015/845041.

77. Ghosh M, Öner D, Duca RC, Cokic SM, Seys S, Kerkhofs S, Landuyt K, Hoet P, Godderis L. Cyto-genotoxic and DNA methylation changes induced by different crystal phases of TiO2-np in bronchial epithelial (16-HBE) cells. Mutation Research. 2017; 796:1-12. https://doi. org/10.1016/j.mrfmmm.2017.01.003.

78. Nassar D, Latil M, Boeckx B, Lambrechts D, Blanpain C. Genomic landscape of carcinogen-induced and genetically induced mouse skin squamous cell carcinoma. Nature Medicine. 2015; 21:946-54. https://doi.org/10.1038/ nm. 3878 . 